University of the Pacific

Scholarly Commons

Summer 9-1-2002

\title{
Insensible Perspiration and Oily Vegetable Humor: An Eighteenth Century Controversy Over Vegetarianism
}

Ken Albala

University of the Pacific, kalbala@pacific.edu

Follow this and additional works at: https://scholarlycommons.pacific.edu/cop-facarticles

Part of the Food Security Commons, History Commons, and the Sociology Commons

\section{Recommended Citation}

Albala, K. (2002). Insensible Perspiration and Oily Vegetable Humor: An Eighteenth Century Controversy Over Vegetarianism. Gastronomica, 2(3), 29-36. DOI: 10.1525/gfc.2002.2.3.29

https://scholarlycommons.pacific.edu/cop-facarticles/31 


\section{Insensible Perspiration and Oily Vegetable Humor}

\section{An Eighteenth-Century Controversy over Vegetarianism}

Quack Diets are nOthing New. Nor have they always been easily dismissed. In eighteenth-century Italy, a virulent controversy arose over a meatless wonder diet. This controversy would eventually play itself out in the field of nutritional theory, as dietary writers scrambled to incorporate the latest scientific findings into their recommendations.

In 1743, an Italian physician, Antonio Cocchi, published a book claiming that everyone would benefit from giving up meat. Cocchi tried to argue the advantages of his vegetarian diet scientifically, and his book, Del Vitto Pitagorico (The Way of Pythagoras), was received with enthusiasm. Two years after its publication, it was translated into English as The Pythagorean diet, of vegetables only, conducive to the preservation of health, and the cure of disease. In 1762 , the book was translated into French. Apparently Voltaire read and admired it. ${ }^{1}$

During this time, rival scientific schools were competing for dominance, and Cocchi was not the only one scrambling to incorporate the new findings into his dietary recommendations. Shortly after the original publication of Del Vitto Pitagorico, two other physicians, Guiseppe Antonio Pujati and Giovanni Bianchi, attacked Cocchi for lacking scientific understanding and for recommending for sick and healthy alike a diet appropriate only for those with specific diseases.

\section{Nutrition Moves to the Periphery}

It was during this time that nutrition began to lose center stage among the medical arts, as the focus - even among authors writing about nutrition - shifted to therapeutics. Since ancient times, nutritional theory and diet had been at the core of professional medical training and practice. "Diet" itself had once had a broader meaning, including careful attention to exercise, air quality, emotions, and sexual activity. The emphasis on nutrition and diet stemmed ultimately from Hippocrates, who had stressed prevention over therapy. In the late seventeenth century, however, this began to change. With the coming of the scientific revolu-
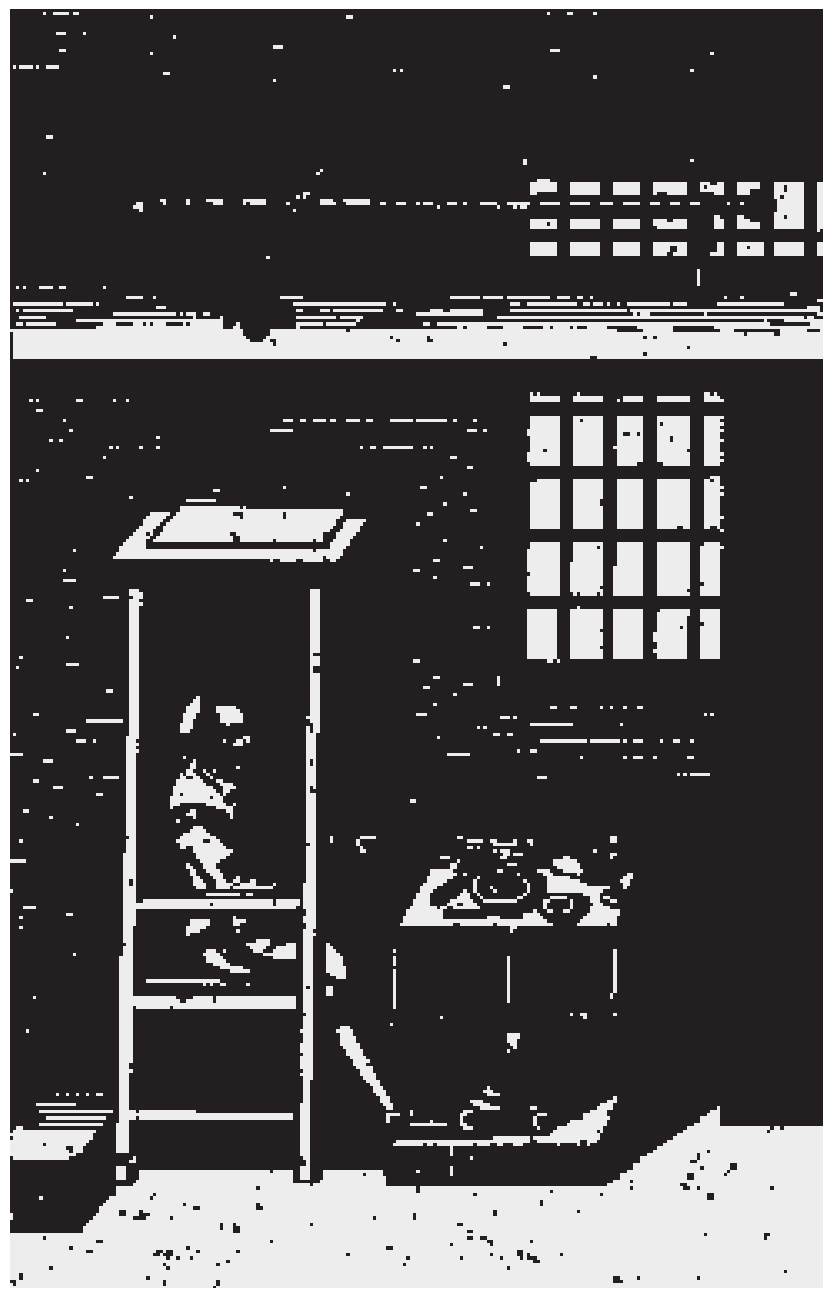

Santorio Santorio in his weighing chair. From Sanctorius Sanctorius, Medicina statica: being the aphorisms of Sanctorius, with introduction by John Quincy (London: W. Newton, 1718), frontispiece.

COURTESY OF WELLCOME LIBRARY, LONDON

tion, physicians began systematically to investigate physiology and even to stumble across effective therapies for their patients' ills. Wrangling over theories of how best to prevent disease gave way to experimentation and an empirical approach to finding cures. Clinical medicine was the hot new topic. Nutrition fell by the wayside, where it has remained ever since. (Most modern medical schools do not 
require a course in nutrition for future practitioners; today's physicians are trained to diagnose, drug, and cut.)

The recommendations of nutritional theorists thus shifted from ways to maintain the average person in health to ways to prevent or treat disease. ${ }^{2}$ In the seventeenth century, the most exciting new research in nutrition was conducted on diseases such as scurvy, gout, and various ailments that were lucrative to treat, including obesity. As the study of nutrition, apart from its role in disease, was displaced from the clinical mainstream, it became difficult for those writing about the subject to keep up with the most recent scientific findings. To gain respect, these writers were obliged to couch their recommendations in the latest scientific terminology, whether they fully grasped it or not. Frequently, they simply pasted this terminology over their basic ideas, which remained unchanged. This practice, much like the shift from prevention to therapy, has left its legacy.

\section{The Way of Pythagoras}

At the time when Cocchi was writing, vegetarian diets were typically prescribed for sick patients, but he recommended that everyone abstain from meat. To bolster his argument, he drew upon the findings of three new schools of physiology. First, there were the Paracelsians or iatro-chemists, who had begun to analyze the chemical constituents of food and to describe certain physiological processes in chemical terms, e.g., as the interaction of salts, sulphur, and mercury. For example, Jan Baptist van Helmont, who belonged to this school, explained digestion as the decomposition of food in an acidic environment. ${ }^{3}$ Second, there were the mechanical investigations of the late seventeenth and the eighteenth century: Giovanni Borelli and the iatro-mechanical school sought to explain physiology in terms of the latest findings in physics. For example, they viewed the body's conduits as little pneumatic pumps controlling the passage of fluids and air through pressure gradients. Last, and most important for the case at hand, was the measurement of "insensible perspiration" proposed in the early seventeenth century by the Italian Santorio Santorio, who considered the quantity of perspiration to be an indication of the rate and force of metabolic activity. In fact, it is upon the validity of Santorio's approach to studying physiology that the entire vegetarian controversy hinged.

These ideas were rather haphazardly combined by Cocchi not only with each other but with the older system of humoral physiology, which had been inherited from the Greeks, particularly Hippocrates and Galen. The Greeks had posited that all foods have inherent qualities - hot, cold, wet, and dry - that affect the "humoral balance" of the person who eats them. A cold cucumber, for example, could cause excessive phlegm and lead to a cold. Although few physicians still discussed sickness as the imbalance of the four principal humors - blood, phlegm, choler, black bilethey still conceived of food as heating or cooling the body, or as drying or moistening it, distinctions that constituted the cornerstone of the old system. Furthermore, humoral physiology still informed much of the popular conception of what went on in the body, even as scientists were groping for other levels of understanding.

Cocchi, in promoting his vegetarian diet, tried to overturn the humoral notions of nutrition by referring to the latest scientific findings. Like those who criticized him, Cocchi drew extensively upon the work of the new schools, especially that of Santorio. Those who criticized Cocchi also used Santorio to support what were essentially Hippocratic ideas. In other words, very old nutritional theories came to be clothed in new garb.

Cocchi's work, oddly enough, not only purported to be a scientific defense of the Pythagorean diet, but a defense of the ancient Greek Pythagoras himself as a wise man whose empirical research led him to make discoveries millennia ahead of their time. Among these discoveries was counted his abstemious vegetarian lifestyle, which "[w]e see at once accords with the best rules of medicine deduced from the most exact modern knowledge of the nature of the human body and the constituents of foods..."4 This idea - that the most ancient authors, such as Moses, Hermes, and Pythagoras, were bearers of the prisca scientia (original wisdom or knowledge) and knew much more than those who followedprevailed throughout the early modern period. Claiming Pythagoras to be an ancient forerunner of the scientific revolution, however, was one of the points Cocchi's enemies found easiest to tear apart.

Essentially, Cocchi's arguments rested on one simple physiological principle: the food that most people eat is far too dry and difficult to digest. The dryness impedes the natural "insensible perspiration." Insensible perspiration is a sure sign that nutrients have been transported throughout the body and that nutritive matter has been assimilated and waste products eliminated. Santorio, writing one hundred years before Cocchi, was not the first to suggest that the body eliminates waste products through perspiration, but he was the first to quantify this process, which he did with his famous weighing machine, on which he systematically weighed himself for years. Comparing the weight of food and drink ingested to that of the residual waste products, which were usually a little lighter than the food, Santorio 
concluded that the remainder exits through the skin's pores and via exhalation. He also calculated which foods produce the most perspiration; these foods he considered to be the most thoroughly incorporated, hence the most nutritious.

\section{Meat Clogs the Passageways}

There is no direct evidence that Cocchi had actually read Santorio's Medicina statica. Nevertheless, taking Santorio's ideas as a starting point, Cocchi concluded that because meat products produce less perspiration than plant foods, they clog the body's passages. Ultimately, therefore, they are less beneficial. A diet of uncooked fruits, vegetables, and clear water would keep people healthy longer and prevent scurvy, gout, and elephantiasis, all of which are a result of crude, indigestible matter remaining in the body. Meats are too glutinous and cohere excessively to the body, causing waste products to accumulate. Optimal nutrition depends on the "subtlety" - the lightness, clarity, and mobility - of the body's fluids: the more subtle the fluids, the more easily wastes can be passed out. "How much then our vital fluids ought to be subtle is manifest in their needing to be gradually refined through insensible perspiration, so exiting the living body." Cocchi was also certain that the sheer volume of fluids in the body promotes transpiration, and here he speaks of blood, liquids, and vapors, not of the four humors. Fruits and plants provide a more readily abundant and usable form of fluid than animal products and even dried vegetable matter. He assumed that Pythagoras abstained from fava beans because they are usually dried. Pythagoras probably would not have disapproved of fresh ones, Cocchi concluded.

In his defense of vegetarianism, Cocchi also drew upon the claims and principles of the other new schools. Vegetables, he insisted, if broken down chemically, contain a great deal of water, some salts and acids, and finally a moderate amount of "oily vegetable humor" (fats). Flesh and eggs, on the other hand, contain an excess amount of "oily vegetable humor." Furthermore, a certain "saponaceous" (soapy) quality in plant matter helps clean out the body's tiniest passages. (At least conceptually, this is not very far from our modern idea that certain foods, e.g., green tea, cleanse the body by destroying free radicals.) Advertising his scientific knowledge, Cocchi also paid lip service to the mechanical school, describing how oily and viscous ("terrestrial") fluids travel more slowly through the body's narrow passages, while lighter and thinner ones move more quickly, thus aiding digestion.

Cocchi assured his readers that this diet does not follow "the poetic imagination of the barbaric school, but hails from the secure light of our times given by anatomic medicine and mechanics, natural history, and experimental physics, of which a part is sound chemistry." By "barbaric school," he meant humoral physiology, which had condemned fruits and vegetables as being too watery and phlegmatic. Cocchi's aim was to replace such outdated nutritional wisdom - something only the ignorant would believe in with proper scientific findings. Vegetables, he claimed, "are not damnable as the vulgar believe, but wonderfully useful and good."

One of the most salient examples of Cocchi's attempt to incorporate science is his rejection of wine. In ancient theory, wine was the analogue of blood, and, as such, it was classed among the perfect nutrients. But Cocchi claimed that wine liquefies the aliments too much, preventing the proper cohesion and agglutination of nutritive matter. At least this was how he explained that Pythagoras's diet was scientifically consistent. Similarly, Cocchi explained Pythagoras's abstention from garlic, onion, leeks, dried fruits, and nuts as an attempt to ward off excessive dryness. Preventing dryness, in fact, was the sole principle that informed Cocchi's vegetarian diet.

Despite his appeal to science, Cocchi himself conducted no experiments. To give his claims an air of legitimacy, it was sufficient-or so he hoped-to mention the new schools.

Where would Cocchi have gotten the idea that dry foods and a dry body lead to premature aging and sickness? Nowhere are such notions mentioned in the ancient descriptions we have of Pythagoras or in the explanations of why he chose to be a vegetarian. Rather, Cocchi's opinions were based on the latest studies of scurvy and gout. More than anything else, it was the study of disease that guided Cocchi's vegetarianism. Disease, in Cocchi's opinion, originates in excessive solidity and the improper flux of waste products: "In general, all sicknesses derive from excessive robustness of the solids, from acrid, rancid and oily and salty fluids, from their thickness and their heavy gluey deposits, and from too vivacious activity moving the internal force." ${ }^{8}$ The latter would have caused excessive perspiration and hence no proper nutrition.

The point is that the physicians' understanding of the causes of gout had informed Cocchi's entire dietary plan, which was proposed for healthy and sick alike. It was not only that people were eating too much meat and not enough fruits and vegetables; in Cocchi's mind, they needed no meat at all.

Cocchi also noted that few vegetables are eaten in times of war, on ocean voyages, or, especially, among the wealthy. It is precisely under these circumstances that scurvy appears. 
C TABitr
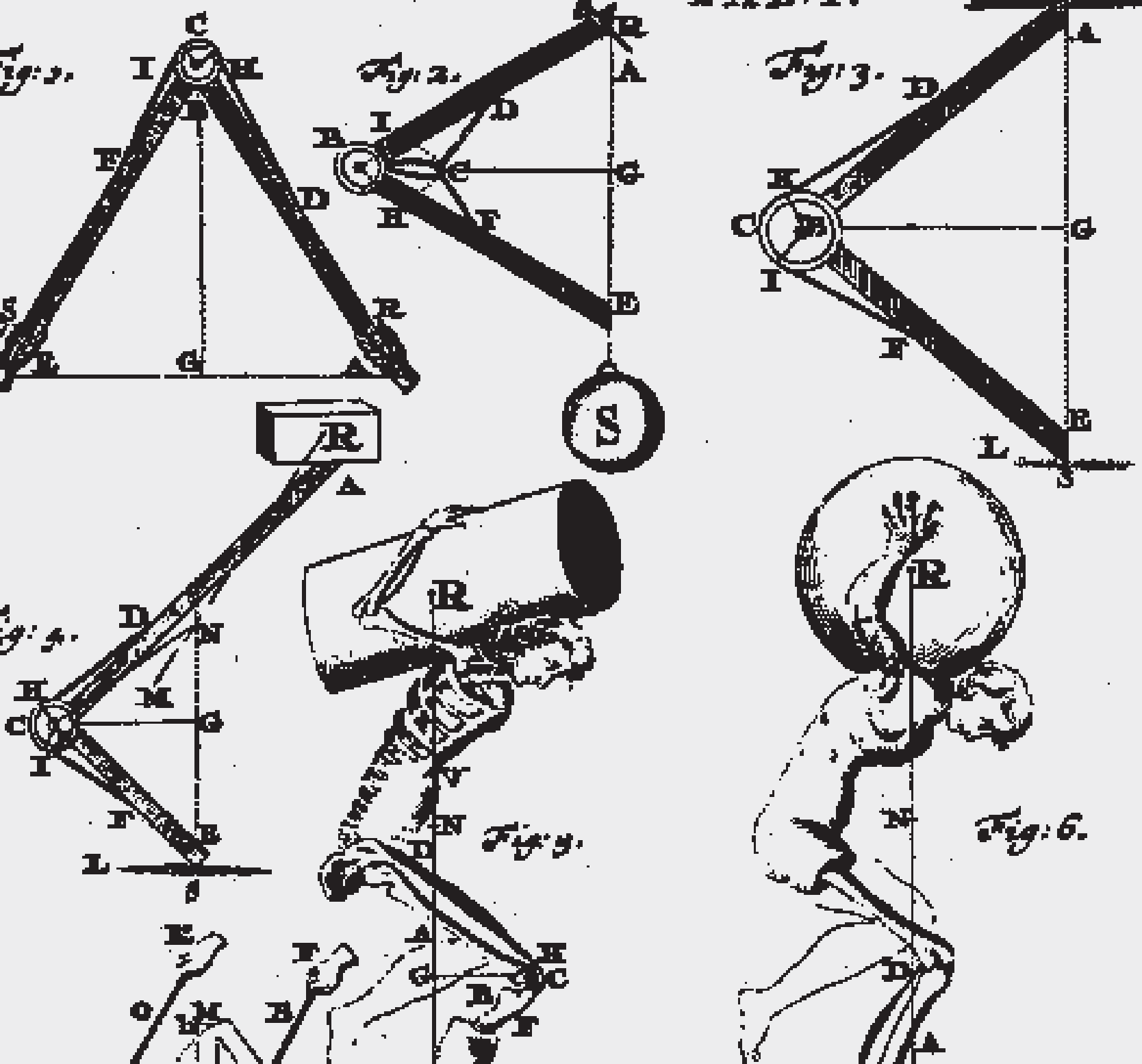

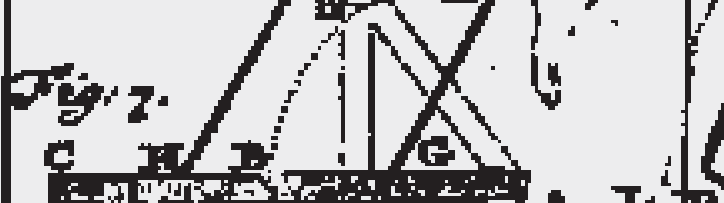

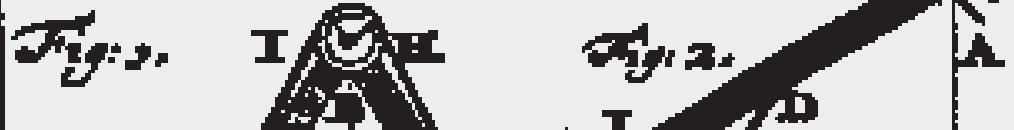
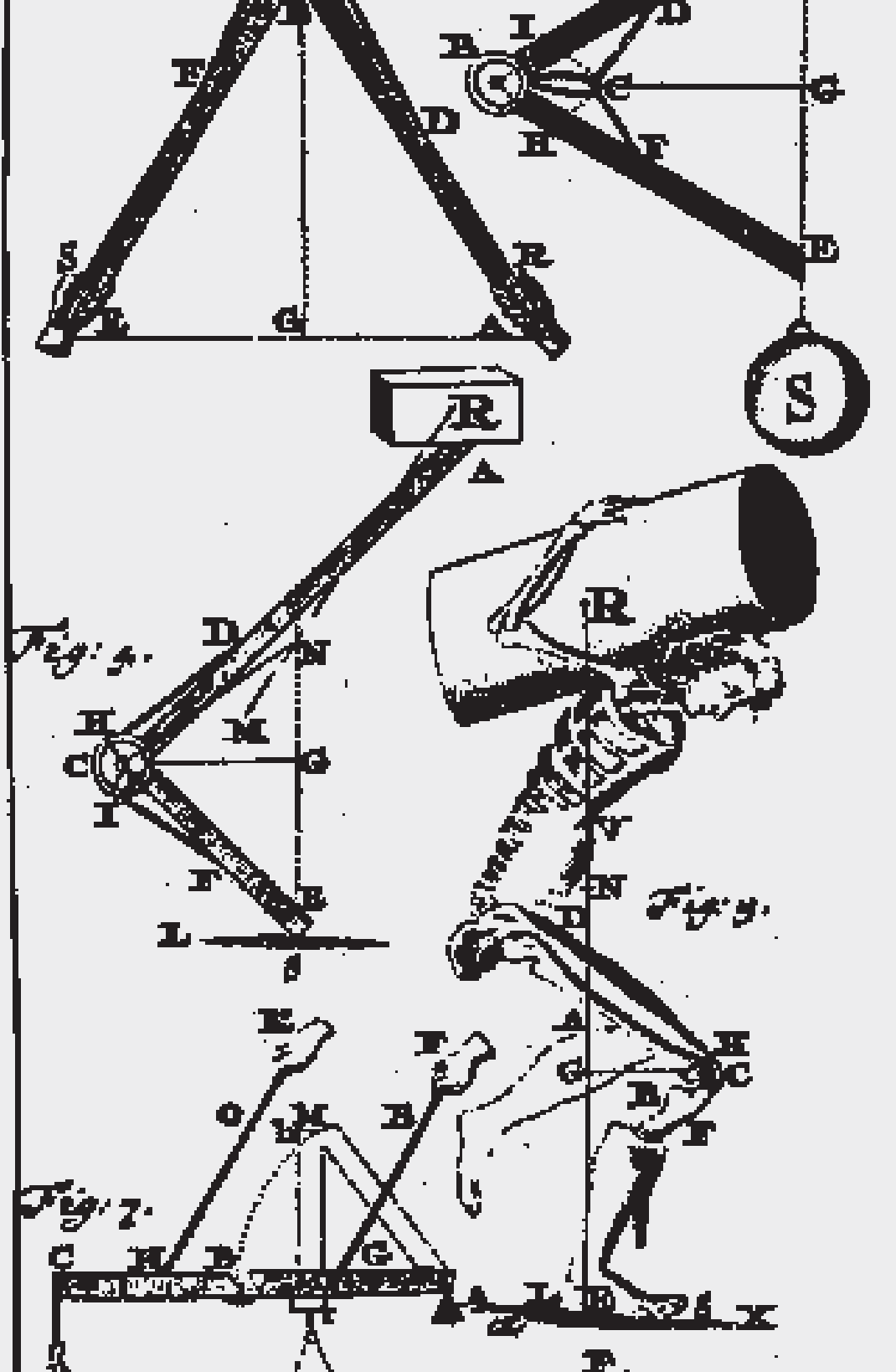
The cause of scurvy is not, as many contended, the poor climate, the sea air, or an excessive consumption of salty meats - it is only the lack of vegetables. Cocchi noted that the number of cases of scurvy increases when a spring snowfall destroys the young green plants. Here, his observations were scientifically sound, but his conclusion - that meats are unnecessary and that people should live entirely on vegetables - is, at best, unwarranted by the evidence he presents.

Again, studies of pathology inform dietary recommendations for the healthy. Cocchi further supported his point-albeit with more anecdotal evidence (of a kind we often see nowadays in connection with the Mediterranean diet) - by remarking that Tuscans are among the healthiest people in the world, and for one principal reason: poverty leads them to eat an abundance of fresh fruits and vegetables and very little meat. Their health stands in stark contrast to that of the average wealthy European, who subsists on an almost entirely meat-based diet.

Not only are there many robust peasants who live on vegetables, especially mountain people, but we should not forget "the Japanese, most ferocious who scorn dangers and death, yet abstain from animals." Thus, Cocchi mustered yet more anecdotal evidence to support the new vegetarian diet and to convince his readers that they need not fear a loss of vigor or energy, qualities they supposedly received from animal flesh.

What exactly did this diet promise? And how did the potential vegetarian hope to be transformed by it? Cocchi's diet is nothing more than an appeal to the literate, affluent reader who hopes to prevent, remove, or mitigate some of the infirmities prevalent in the eighteenth century. In this respect, it is remarkably modern: its goal was to prevent fashionable diseases, rather than to promote health more generally.

\section{The Way of Pythagoras Under Fire}

In many regards, the attacks on Cocchi's work are even more interesting than his book itself. Name-dropping at every opportunity, his critics made a concerted appeal to science. Ironically, their criticism of Cocchi's vegetarianism ultimately relied on ideas that were over two thousand years old. Their attacks accorded well with the Hippocratic tradition and the notion of humors, the toga barely hidden beneath a waistcoat and a starched wig.

Left: A demonstration of leg joints. From Giovanni Alfonso Borelli, De motu animalium (Leyden: P. Vander Aa, etc., 1685), plate facing p.64, table IV.

COURTESY OF WELLCOME LIBRARY, LONDON
In 1751, Guiseppe Antonio Pujati, a physician of Feltre (north of Venice), published the first attack, entitled Riflessioni sul vitto Pitagorico. Pujati tore apart Cocchi's argument that Pythagoras was some kind of primeval scientist, a precursor of Galileo or Bacon. Pythagoras did, indeed, counsel sobriety, but one need not be a scientific physician to do that. From Pujati's very region, in fact, had come the great sixteenth-century health guru Alvise Cornaro, who lived to extreme old age, eating an extraordinarily frugal diet. But Cornaro was no physician, either. Nor do we have any texts proving that Pythagoras approached the topic of diet in any scientific or methodical way or even that he was a scientist, in the modern sense of that word.

Pujati's real attack, though, was leveled against Cocchi's faulty use of science. Pujati conceded that vegetables promote the rapid transit of fluids through the body and that they aid the "insensible perspiration." However, while vegetable matter may be easy to digest, actually it is too easy, as it promotes an excessive elimination of fluids. Pujati also seems to have been suggesting that what we call roughage - the indigestible fibers - causes food to pass too quickly through the body. (Interestingly, even modern scientists have not yet agreed on whether roughage is, in fact, beneficial.) To illustrate his point, Pujati suggested that the excrement of herbivores be examined, as well as the excessive amount of undigested fibers remaining therein. Vegetables, Pujati concluded, offer less nutritional value than other foods because so much of their mass is expelled from the body, sometimes with purgative force. As we would say, they don't stick to the ribs.

Pujati contended that the liquid part of vegetable matter is essentially indigestible, too. That onions and garlic leave a lingering odor on the breath is a sure sign that they have not been properly converted by the body. Since they do cut through the body's gluey fluids, logically they should have been recommended by Pythagoras himself, that "most clear illustrator of the vegetable diet," as Pujati sarcastically remarked. ${ }^{10}$ But Pythagoras shunned onions, and that, for Pujati, is an inexcusable inconsistency in Cocchi's argument. Even more irrational, Pujati thought, was Cocchi's use of Santorio's data. Just because vegetables make you sweat more does not mean that they must be better for you than meat.

Armed with a full store of Hippocratic ammunition, Pujati proceeded to illustrate just how dangerous vegetables really are. He recounted numerous personal experiences of country people and city dwellers who picked wild herbs and ended up suffering horrible intestinal problems, vomiting, and diarrhea. Pujati claimed it was the vegetables that caused these problems, rather than a water-borne virus or cholera. Furthermore, Pujati provided examples based on his own 
clinical experience that poverty-stricken people who live on vegetables are never robust and healthy. Quite the opposite. ${ }^{11}$ The idea of healthy poverty, he insisted, is a myth. Pujati probably had seen many cases of what we now call pellagra in the Veneto, where the poorest people subsisted largely on polenta made from corn.

Pujati's arguments were actually a bizarre blend of some of the latest scientific studies and Hippocratic and Galenic teachings, which condemned most fruits and vegetables. Hippocrates, Pujati reminds us, thought fruits difficult to digest and "corruptible." Furthermore, renowned physician "Vobiscus Fortunatus Plemp...says first that fruits are crammed full of worms visible with a microscope, and that because of this the use of them can lead to extraordinary and dangerous diseases. Secondly, they cause bad dreams, which disturb the sleep." 12

Cocchi's claim that fruits are easily digested is also unfounded, according to Pujati. Grapes, for example, are light and easily eaten, but the skin is utterly indigestible. Pujati cites recent experiments, insisting throughout that it is scientific observation and reason, linked with the voice of authority, that prove his case. And, unlike Cocchi, Pujati conducted experiments. For one experiment, he began by making two separate broths, one of meat and vegetables, the other of vegetables alone. Even though the volume of the ingredients was the same in both cases, the broth with meat weighed more, which was proof to him that it contained more nutritive matter. "For it is not only practical observation, but reason that is sufficiently plausible, because treated with experiment, not just hypothesis."13 Pujati seems to have believed that any experiment, even this absurdly superficial one, would strengthen his argument.

Pujati went out of his way to show that his scientific knowledge far exceeded Cocchi's. For example, citing Hippocrates, he pointed out that foods that are not completely digested, like vegetables, necessarily cause gas. Hippocrates could be forgiven because there were no pneumatic instruments or barometers in his day, but with a "pneumatic" experiment, the production of gas could be proved. Pujati referred to an experiment performed by the physicist Stephen Hales, who, in De flatibus (On flatulence), showed that seventeen cubic inches of blood and water produced fourteen cubic inches of "air," whereas seventeen cubic inches of honey and water produced 968 cubic inches, or about seventy times the volume. Not knowing that sugars fermenting produce carbon dioxide, Pujati concluded that vegetables cause unnatural fermentation in the stomach, which is why they cause gas. He also cited an experiment by Robert Boyle, the great English physicist whose eponymous law is still memorized by every high-school chemistry student. Here, as elsewhere in Pujati's work, scientific "proof" is dragged out to lend an air of authority to what remains essentially unsubstantiated opinion.

Pujati's treatise does at least provide evidence of careful reading of scientific experiments undertaken by others in a way that Cocchi's work did not. Pujati cites Santorio's work, certainly from firsthand knowledge, to the effect that not all vegetables promote "insensible perspiration." Cucumbers, for example, impede it, and some foods (melons, grapes, fresh figs) even prevent the perspiration of other foods. In other words, Cocchi had seized upon a basic principle in Santorio without having read the fine print. Pujati also demonstrated his superior knowledge of the so-called "solidist" school. Rather than paying lip service to mechanistic theories to resolve the question of whether digestion was a chemical or a physical process (or perhaps both), Pujati claimed: "[I]n digestion fermentation does intervene, so I do not believe the rigid solidist, I deny that it is only sustained by a machine."14 Pujati also discussed at length the work of Hermann Boerhaave, the Dutch physician who made the University of Leiden's medical school the best in Europe. Boerhaave's ideas about stomach acids and the use of alkali or antacid to treat intestinal disorders should have been well-known to any competent physician.

But a little science can be a dangerous thing. Anything can be proved, or at least proved sufficiently for a gullible audience, with a few experiments and a few numbers. Pujati's arguments remain thoroughly Hippocratic; his conclusions, anything but scientific proofs. Haphazard appeals to science have remained a regular feature of popular writing on nutrition right down to the present. Before 1650, however, this had not been the case - the stamp of authority and perhaps experience had provided the criteria for truth. But after 1650 or so, any kind of experiment-logical, relevant, or otherwise-served as "proof."

Pujati admitted that Cocchi was right to point out that many people consume too much meat, and that fruits and vegetables contain a lot of water and serve to clean out and lighten the body by promoting evacuation and perspiration. All this, Pujati agreed, is true. But these are medicinal properties, valuable for those who have overindulged or for the infirm. Vegetables, insofar as they cleanse the body, are not aliments, merely correctives. For all his appeal to science, Pujati took what is still basically a Galenic position. Meat is what nourishes, and vegetables should be used to "correct" the deficiencies of a too-heavy diet. Vegetables are a remedy - nothing more. For Pujati, the notion that one should subsist on plants and water alone defied reason. 


\section{Bianchi Joins the Fray}

Yet another attack on Cocchi was published in 1752. This was Se il vitto pittagorico di soli vegetabili sia giovevole per conservare la sanità, a per la cura d'alcune malatie, written by Giovanni Bianchi, the town physician for Rimino. Bianchi had actually delivered his paper several years earlier, in 1747, in Florence at the Accademia de' Lincei. Like Pujati, Bianchi criticized Cocchi for all the absurdities he had spouted about Pythagoras. Bianchi's principal concern, however, was the vegetarian diet. He began with the practicality of it. Would it even be possible to subsist on raw vegetables in cold countries, where fresh produce is not always available and where people have to cook their food for warmth? "The greater part of the world, or the most beautiful, would be depopulated in a few hours for not being able to last through the winter because of a lack of fresh fruits and green herbs necessary to sustain life." 15

To further support his claim against vegetarianism, Bianchi mustered evidence from Hippocrates, as well as from the more recent scientific findings. Bianchi asserted that Cocchi's book did not accord with the latest knowledge of the human body. Bianchi, too, had read a bit more science and could see immediately the superficiality of Cocchi's claims. He even purported to describe the chemical constituents of certain foods. "Certainly herbs and fruits are composed of things very different than our flesh, our blood and our parts, as chemical analysis easily shows." 16 This was why "herbs and fruit" could not provide suitable nourishment. In fact, the ancient idea that the body can be nourished only by substances similar to it informs Bianchi's entire condemnation of vegetarianism. Thus, Bianchi was using eighteenth-century science to prove medical precepts of two thousand years earlier. (This is not to suggest that his ideas are complete nonsense. In fact, he cites an experiment in which bread was chemically analyzed and found to have an acidic principle, a vegetable principle, and a gelatinous, alkaline principle, which was akin to animal substances. Without knowing it, he was, of course, referring to gluten, the protein found in bread. Bianchi's conclusion that the presence of gluten made bread the most nourishing of vegetable substances is not far from our present understanding of nutrition. What is interesting is his bizarre combination of traditional dietetic ideas jumbled with what might be called the earliest food science.)

Another of Cocchi's arguments that Bianchi proceeded to destroy is that we were meant to eat vegetables because of the anatomy of our mouths, our flat teeth, and our lack of sharp claws. Flaunting his superior knowledge of anatomy,
Bianchi pointed out that we are strikingly different from herbivores, whose ruminant stomachs and larger colon make a vegetable diet feasible. Rather, humans resemble omnivores, like bears, which eat both animal and vegetable foods.

His principal criticism of Cocchi, however, was to point out the latter's inconsistency. It is true that over-consumption of meats can promote sicknesses such as scurvy, leprosy, and elephantiasis: "I concede that the immoderate use of meat without the mixture of vegetable matter produces a thickening of our blood and of other fluids in our body, which for this reason corrupt, and give rise to various maladies." 17 He had in mind the very wealthy, but Lapplanders, he said, are also a perfect example of those who are subject to scurvy for lack of vegetables. Bianchi agreed with Cocchi that vegetables have acrid, saponaceous qualities that cleanse the blood. But if that is the case, then why exclude from the Pythagorean diet such vegetables as onions, garlic, and radishes? And why prohibit spices like pepper, ginger, and cloves, which scour the body's passages and prevent scurvy? The reasoning here was perfectly Hippocratic. What Bianchi failed to realize was that Cocchi's departure from classical sources was intentional.

Bianchi was willing to admit that a diet of meat alone is harmful, but so, too, would be a diet of only raw fruits and vegetables. On top of that, a diet without wine was unthinkable. Favoring a balanced but varied diet - in fact, the more kinds of food consumed, the better-Bianchi even proposed that people try certain meats that had gone out of fashion, like dog, wolf, donkey, and horse. (Northern Italians seem to have taken his advice regarding horse!) New kinds of vegetables, like corn, should also be promoted. Above all, moderation is the key.

Fruits and vegetables contain many beneficial chemical properties, but some of these are highly acrid and corrosive, e.g., vitriolic salts, nitrous compounds, and sulphurous compounds. More generally, every food has its proper use, and even the most beneficial food can be harmful in excess. Vegetables are indispensable, but they should not be all we eat. To suggest that a vegetarian diet recommended for certain maladies should be universally applied for all people, whether healthy or sick, was, for Bianchi, a flagrant error.

\section{Diets Are Not For Everyone}

What Bianchi was pointing to here is the theme outlined at the beginning of this paper: Cocchi had let the latest pathological findings inform his entire dietetic plan, when in fact the diet ought only to have served to cure, or to mitigate the effects of, particular illnesses. This sort of extrapolation, 
from dietary measures recommended for a few diseaseafflicted individuals to recommendations for the general population, pervades nutritional thought right down to the present. In an effort to avoid certain diseases, standard dietary recommendations get slanted and skewed. The cart pulls the horse. If the point of nutritional science is to maintain health and prevent disease, then can the study of pathological states really offer an accurate guide to the best nutritional principles for everyone?

The argument over vegetarianism recounted here marks a departure from "hygiene" (in the older sense of regulating health by means of diet, exercise, etc.) and an embrace of diets, which were initially designed to help people avoid specific diseases. This little episode is only one example of the tendency to extend dietary recommendations, originally drawn up in response to (and as therapy for) specific diseases, to a much larger group. Several other examples might be cited, such as the furor of the past few decades over whether reducing sodium intake cures hypertension, or the present concern with cholesterol, a concern that initially targeted those at risk for heart disease.

Thus, we have not shaken off the legacy of the shift that occurred in the late seventeenth and eighteenth century: our own nutritional principles are still driven by pathology. If blame could be placed anywhere, it would have to be on science, or more precisely, on one of the expectations that science sets up - that is, that once there is a measurable parameter, measurement in and of itself has explanatory power. In the case discussed here, the measurable parameter was "insensible perspiration." Such measurement was regarded (at least by Cocchi) as a valid basis from which to evaluate the nutritive capacity of various categories of foods. The idea that any new experimental procedure or means of quantification (e.g., statistics) offers unshakeable proof is certainly naïve, however prevalent. Nevertheless, anyone writing about nutrition - now as in the past - is obliged to refer to these studies. Interpretation is often superficial (as in many popular nutrition guides); misinterpretation abounds. This little controversy over vegetarianism, as isolated as it may have been, nonetheless shows in capsule form the direction that nutritional science would take in the two hundred fifty years that followed. @
NOTES

I would like to extend my thanks to the Biblioteca Internazionale "la Vigna" in Vicenza for allowing me to read their copies of these texts. Particular thanks are due the staff for offering their generous and invaluable assistance.

1. Colin Spencer, The Heretics Feast: A History of Vegetarianism (Hanover and London: University Press of New England, 1995), 229.

2. J. Trémolières, "A History of Dietetics," in Progress in Food and Nutritional Science 1, no. 2 (1975): 96-100. Throughout this article, the author shows how diseases, scurvy in particular, came to dominate discourse on nutrition after the mid-seventeenth century.

3. Allen Debus, The Chemical Philosophy: Paracelsian Science and Medicine in the Sixteenth and Seventeenth Centuries (New York: Science History Publications/ Neale Watson Academic Publications, 1977).

4. Antonio Cocchi, Del vitto pitagorico (Firenze: Francesco Moücke, 1743), 29. The translations, here and elsewhere, are mine.

5. Ibid., $47^{-48 .}$

6. Ibid., 40

7. Ibid., 50 .

8. Ibid., 64

9. Ibid., 81 .

10. Giuseppe Antonio Pujati, Riflessioni sul vitto pitagorico (Feltre: Odoardo Foglietta, 1751), 38 .

11. Ibid., $77-78$.

12. Ibid., 49 .

13. Ibid., 55 .

14. Ibid., 6o. On "solidist" theory, see J. Worth Estes, "Food as Medicine," in The Cambridge World History of Food, edited by Kenneth F. Kiple and Kriemhild Coneé Ornelas (Cambridge: Cambridge University Press, 2000), 1538.

15. Giovanni Bianchi, Se il vitto pittagorico di soli vegetabili sia giovevole per conservare la sanità (Venezia: Giambatista Pasquali, 1752), 33.

16. Ibid., 40.

17. Ibid., 62. 